\title{
25. RADIOLARIANS FROM THE SOUTHERN MEXICO ACTIVE MARGIN, DEEP SEA DRILLING PROJECT LEG 66 ${ }^{1}$
}

\author{
Kenneth J. McMillen, Gulf Science and Technology Company, Pittsburgh, Pennsylvania
}

\begin{abstract}
Radiolarians occur at all Leg 66 drill sites and permit biostratigraphic zonation of most sediments. Sedimentary and ecologic effects that create dating problems are (1) dilution by terrigenous sediments in trench and lower slope environments, (2) dissolution and recrystallization of radiolarian tests, (3) loss of most or all of the nassellarian radiolarian fauna in early Pleistocene and late Pliocene sediments, and (4) mixing and loss of faunas due to East Pacific upwelling and transportation by eastern boundary currents. Some or all of these problems may affect dating of older accretionary zone sequences. Coarse-grained trench sediments are best dated by sampling overlying lower slope sequences where reworking and dilution effects are reduced.
\end{abstract}

\section{INTRODUCTION}

Radiolarians occur at all Leg 66 drill sites (Table 1) on the southern Mexico margin. Most abundant faunas occur in upper and middle slope sediments; abundances are much reduced in lower slope and trench sediments because of terrigenous dilution. Reworked radiolarians occur everywhere but are especially prevalent on the middle slope. Pelagic brown clay sediments of the northern Cocos Plate have a poorly preserved fauna, but radiolarian abundance increases in hemipelagic sediments near the Middle America Trench.

Lower Miocene sediments cored at Sites 489 and 493 were the oldest recovered and contain an abundant radiolarian fauna. Middle Miocene sediments were absent at these sites owing to erosion or nondeposition. Upper Miocene sediments recovered at Sites 487, 490, 492 , and 493 generally had a fair to good radiolarian fauna. Pliocene sediments present at Sites 487, 490, 491, 492 , and 493 generally have a somewhat poorer fauna with some dissolution evident. The Quaternary sediments recovered at all sites had an excellently preserved fauna, and upper Quaternary radiolarians were especially well preserved and abundant.

\section{RADIOLARIAN ZONATION}

Previous workers have established a precise radiolarian zonation for Tertiary sediments of the Pacific Ocean (Riedel and Sanfilippo, 1971; Dinkelman, 1973). Quaternary sediments have been zoned separately in high latitudes (Hays, 1970) and in the equatorial regions (Nigrini, 1971). In this report, no attempt is made to modify the existing zonations, because sediments of the southern Mexico margin have many reworked radiolarians and the nearshore environment has an incomplete fauna (Table 2).

Radiolarian occurrences are recorded in Tables 3 through 9 from observations made on strewn slides.

\footnotetext{
${ }^{1}$ Initial Reports of the Deep Sea Drilling Project, Volume 66.
}

Table 1. Site locations, Leg 66.

\begin{tabular}{|c|c|c|c|c|c|}
\hline Hole & Latitude & Longitude & Location & $\begin{array}{c}\text { Water } \\
\text { Depth } \\
\text { (m) }\end{array}$ & $\begin{array}{l}\text { Drilling } \\
\text { Penetration } \\
\text { (m) }\end{array}$ \\
\hline 486 & $15^{\circ} 55.37^{\prime} \mathrm{N}$ & $99^{\circ} 08.10^{\prime} \mathrm{W}$ & trench & 5142 & 38.0 \\
\hline $468 \mathrm{~A}$ & $15^{\circ} 54.83^{\prime} \mathrm{N}$ & $99^{\circ} 08.28^{\prime} \mathrm{W}$ & trench & 5138 & 22.0 \\
\hline 487 & $15^{\circ} 51.21^{\prime} \mathrm{N}$ & $99^{\circ} 10.52^{\prime} \mathrm{W}$ & outer slope & 4764 & 181.7 \\
\hline 488 & $15^{\circ} 57.10^{\prime} \mathrm{N}$ & $99^{\circ} 01.66^{\prime} \mathrm{W}$ & lower inner slope & 4254 & 429.0 \\
\hline 489 & $16^{\circ} 16.19^{\prime} \mathrm{N}$ & $99^{\circ} 01.13^{\prime} \mathrm{N}$ & mid inner slope & 1240 & 34.5 \\
\hline $489 \mathrm{~A}$ & $16^{\circ} 16.19^{\prime} \mathrm{N}$ & $99^{\circ} 01.13^{\prime} \mathrm{W}$ & mid inner slope & 1240 & 298.5 \\
\hline 490 & $16^{\circ} 09.56^{\prime} \mathrm{N}$ & $99^{\circ} 03.34^{\prime} \mathrm{W}$ & mid inner slope & 1761 & 588.5 \\
\hline 491 & $16^{\circ} 01.74^{\prime} \mathrm{N}$ & $98^{\circ} 58.33^{\prime} \mathrm{W}$ & mid inner slope & 2883 & 542.0 \\
\hline 492 & $16^{\circ} 04.73^{\prime} \mathrm{N}$ & $98^{\circ} 56.72^{\prime} \mathrm{W}$ & mid inner slope & 1935 & 279.0 \\
\hline $492 \mathrm{~A}$ & $16^{\circ} 04.73^{\prime} \mathrm{N}$ & $98^{\circ} 56.72^{\prime} \mathrm{W}$ & mid inner slope & 1935 & 70.8 \\
\hline $492 B$ & $16^{\circ} 04.73^{\prime} \mathrm{N}$ & $98^{\circ} 56.72^{\prime} \mathrm{W}$ & mid inner slope & 1952 & 290.0 \\
\hline 493 & $16^{\circ} 22.86^{\prime} \mathrm{N}$ & $98^{\circ} 55.53^{\prime} \mathrm{W}$ & upper inner slope & 645 & 670.5 \\
\hline $493 \mathrm{~A}$ & $16^{\circ} 22.86^{\prime} \mathrm{N}$ & $98^{\circ} 55.53^{\prime} \mathrm{W}$ & upper inner slope & 645 & 12.0 \\
\hline 493B & $16^{\circ} 22.86^{\prime} \mathrm{N}$ & $98^{\circ} 55.53^{\prime} \mathrm{W}$ & upper inner slope & 645 & 126.0 \\
\hline
\end{tabular}

Abundances of taxonomically useful species are noted, based on the scheme devised by Riedel and Sanfilippo (1971), as “abundant"' (A), "common"' (C), "few" (F), "rare" (R), and "very rare" (+). Reworked individuals are marked by an asterisk $\left({ }^{*}\right)$. Intervals in which a species was searched for but not found are marked with a dash (-).

Quaternary radiolarians occur at all sites. The generally abundant fauna is diluted by coarse terrigenous sediments at trench Site 486 . Early Quaternary radiolarians are generally well preserved and fairly abundant except where diluted by lower slope and trench sediments at Site 488 or where partially dissolved at Cocos Plate Site 487 and upper slope Site 493.

Pacific Quaternary radiolarian zonations of Nigrini (1971) and Hays (1970) cannot be applied to Leg 66 sediments because of the absence of many index species. Collosphaerids used in the later Quaternary tropical zonation of Nigrini are very rare to absent. Most index species for Hays's Quaternary zonation are likewise very rare to absent; only Axoprunum angelinum (= Stylatractus universus) is common enough to be a useful index fossil. Rather than mix recognizable zones, I have used only the extinction levels of $A$. angelinum at 0.40 
Table 2. Neogene radiolarian zonations.

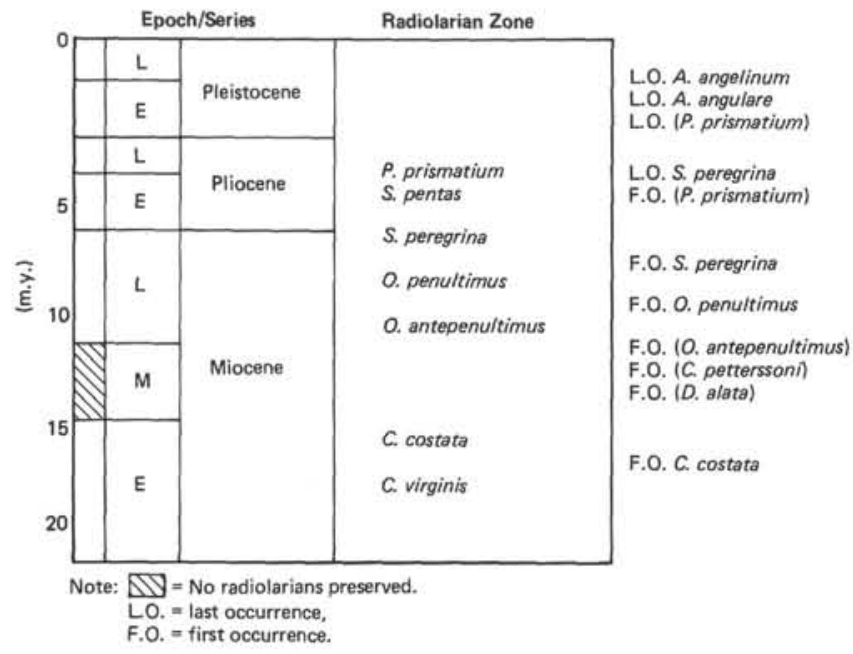

m.y. (Hays, 1970) and of Anthocyrtidium angulare at 1.15 m.y. (Berggren and van Couvering, 1974) as datum levels. The Axoprunum angelinum datum occurs between Sections 8,CC and 9-4 in Hole 487, between Sections $18, \mathrm{CC}$ and $19, \mathrm{CC}$ in Hole 488, within Core 1 in Hole 490, between Sections 1,CC and 2-1 in Hole 491, and between Sections 2,CC and 3-1 in Hole 492. A. angelinum is absent in upper Quaternary sediments at Site 493, even though radiolarians are preserved downsection past the Brunhes/Matuyama boundary of 0.7 m.y. The Anthocyrtidium angulare extinction level occurs only within Core 18 in Hole 490 and within Core 3 in Hole 491 . Erosion at Sites 489 and 492 removed early Quaternary sediments that included this datum level. Nonpreservation of most early Quaternary radiolarians at Sites 487 and 493 precludes recognition of this datum.

Pliocene sediments have the most poorly preserved radiolarian fauna. Absence of Pterocanium prismatium makes the $P$. prismatium Zone difficult to impossible to recognize. On the other hand, the presence of the Stichocorys peregrina extinction allows recognition of the top of the Spongaster pentas Zone at Sites 490, 491, 492 , and 493 . The absence of $P$. prismatium complicates recognition of the top of the Stichocorys peregrina Zone (Table 1), but the evolution of Spongaster pentas, which occurs near this boundary in the East Pacific (Dinkelman, 1973), permits a reasonable extrapolation of the zone boundary at Sites 490, 492, and 493.

Upper Miocene sediments contain a well-preserved and abundant radiolarian fauna that often contrasts with poorly preserved to nearly barren assemblages in Pliocene sediments. The first occurrence of Stichocorys peregrina allows recognition of the top of the Ommatartus penultimus zone at Sites 492 and 493 . The $O$. penultimus zone is inferred at Site 487 from the presence of $S$. delmontensis and the absence of $O$. hughesi (Riedel and Sanfilippo, 1971). The top of the $O$. antepenultimus Zone is recognized by the evolutionary appearance of O. penultimus at Sites 492 and 493 ; but at Site 487 this zone is recognized by the presence of $O$. hughesi, whose extinction level occurs near or at the top of the $O$.
Table 3. Radiolarians at Site 487.

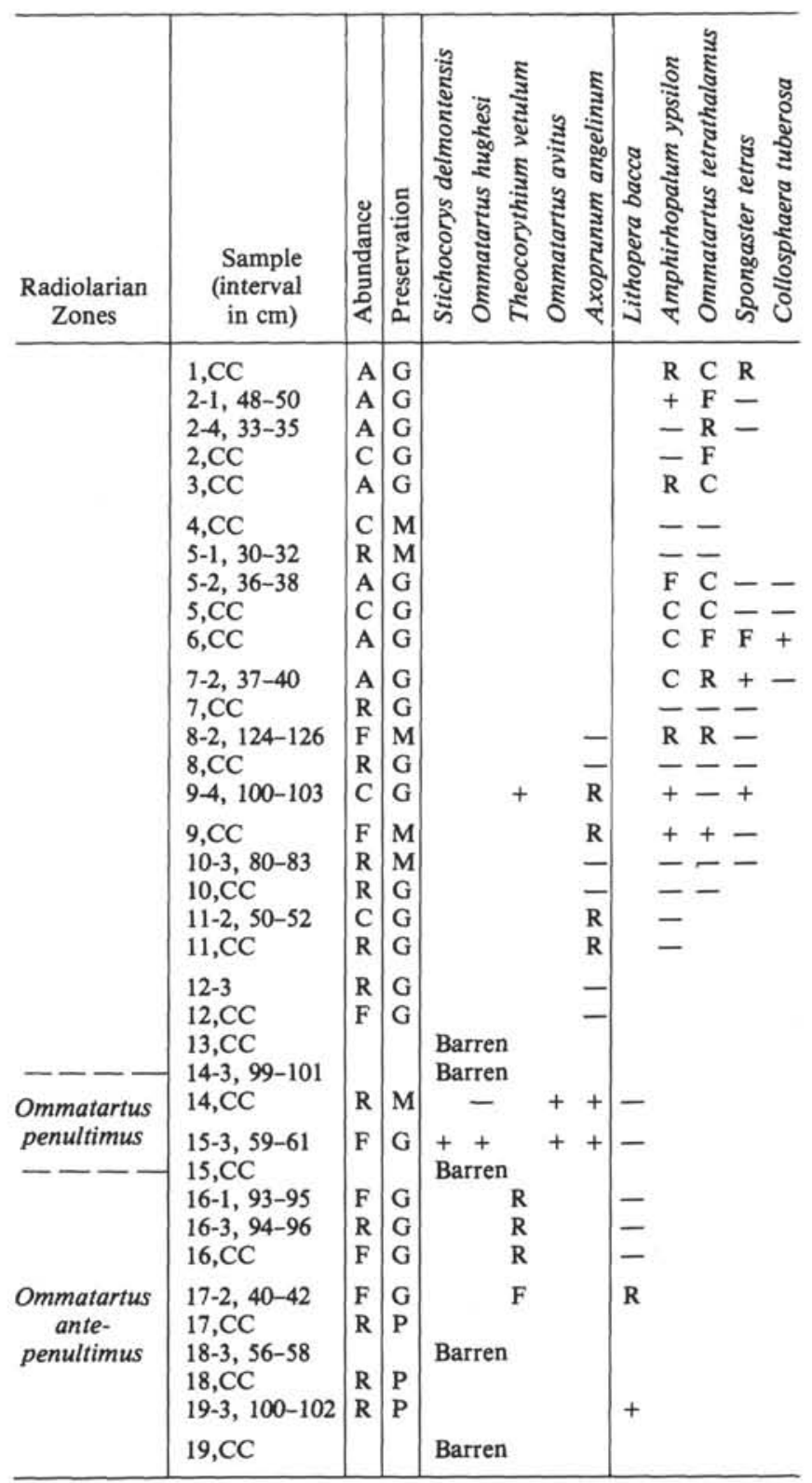

antepenultimus Zone (Dinkelman, 1973; Riedel and Sanfilippo, 1971, 1978). The base of the $O$. antepenultimus Zone was not penetrated at Sites 487 and 492, and at Site 493 it occurs within an unconformity.

Middle Miocene sediments are absent from Leg 66 cores. At Sites 489 and 493, the middle Miocene is represented by an unconformity; at other sites there was insufficient penetration. Reworked middle Miocene radiolarians are very scarce or possibly even absent. No reworked radiolarians with ranges restricted to the middle Miocene have been found, and only a few middle to upper Miocene reworked forms occur such as Cannartus laticonus, $C$. petterssoni, and $S$. delmontensis.

Lower Miocene sediments in Sites 489 and 493 contain abundant well-preserved radiolarians in the upper portion of the section. Recrystallization of radiolarians 
Table 4. Radiolarians at Site 488.

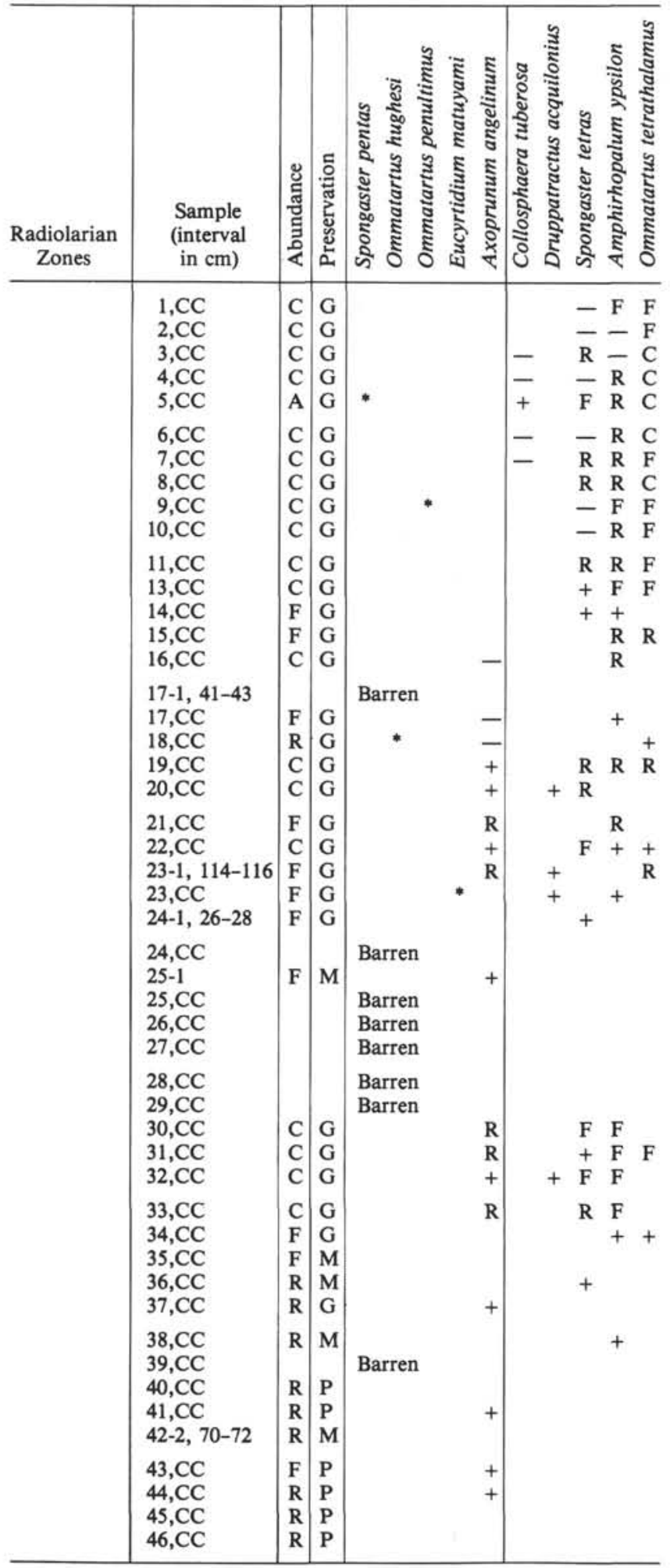

toward the Oligocene/Miocene boundary makes taxonomic identification impossible. The early Miocene Calocycletta costata and C. virginis zones are recognized at Site 489 by the evolutionary appearance of $C$. costata in Core 2 (Riedel and Sanfilippo, 1971). Only the C. costata Zone is recognized at Site 493 before
Table 5. Radiolarians at Site 489.

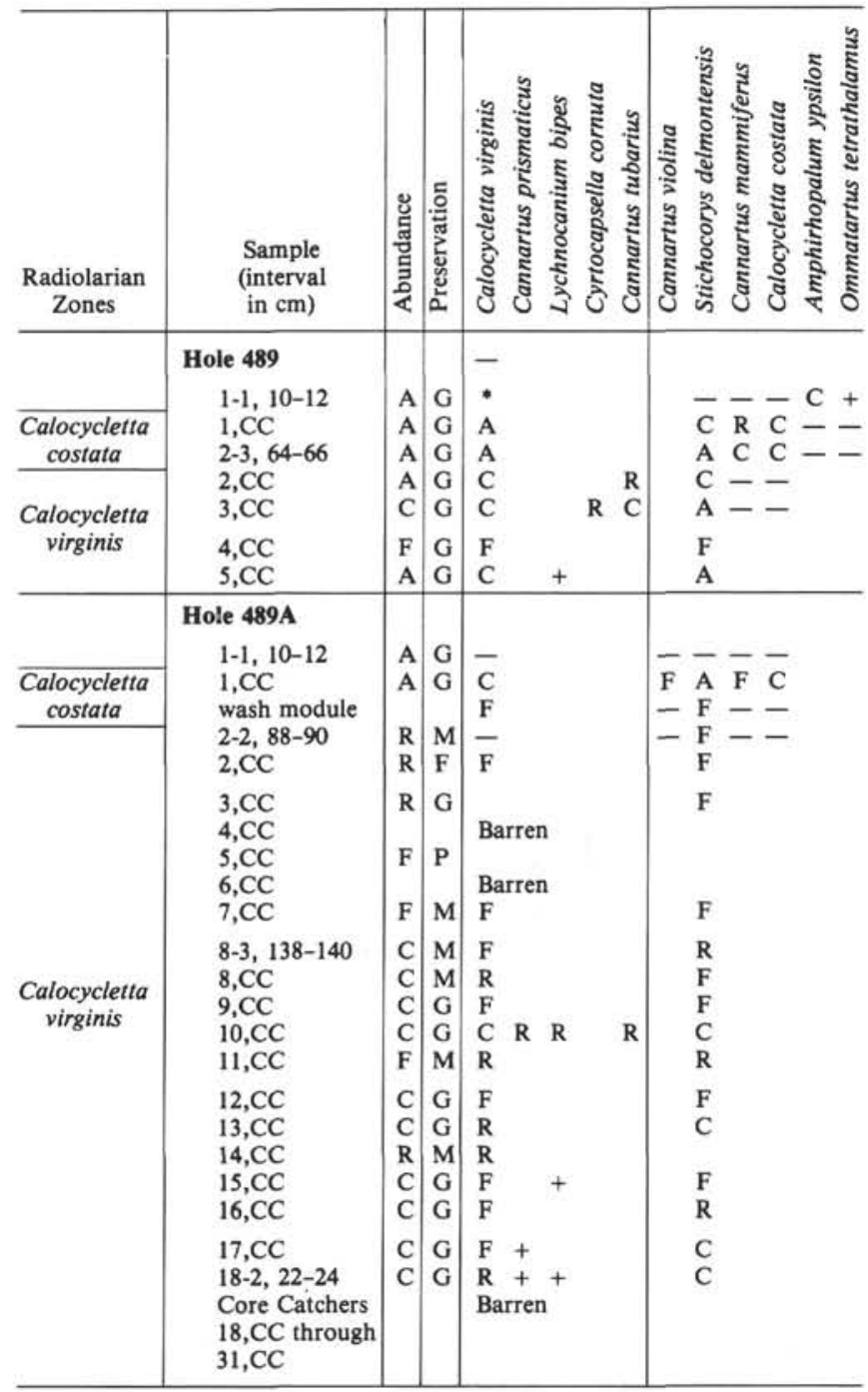

radiolarian recrystallization precludes identification below Core 493-35. The $C$. costata/C. virginis boundary occurs within the NN4 Zone at Site 489, yet Berggren and van Couvering (1974) correlate this boundary with the NN3 Zone. Whether the data from calcareous nannoplankton or radiolarians are erroneous or the boundary is really different could not be determined.

\section{DISCUSSION}

Micropaleontological study of the Leg 66 active margin drill sites illustrates the potential problems and complexity in dating older accretionary zone sequences exposed in orogenic belts. Some of the problems complicating radiolarian biostratigraphic determinations are the following: (1) poor faunal preservation, (2) reworking of older microfossils, (3) an incomplete fauna lacking some critical index species, and (4) mixing of faunas due to oceanographic effects associated with the eastern boundary current.

Radiolarian preservation is good in upper Quaternary and Miocene sediments and poor in Pliocene and lower Quaternary intervals. Locally barren intervals 
Table 6. Radiolarians at Site 490.

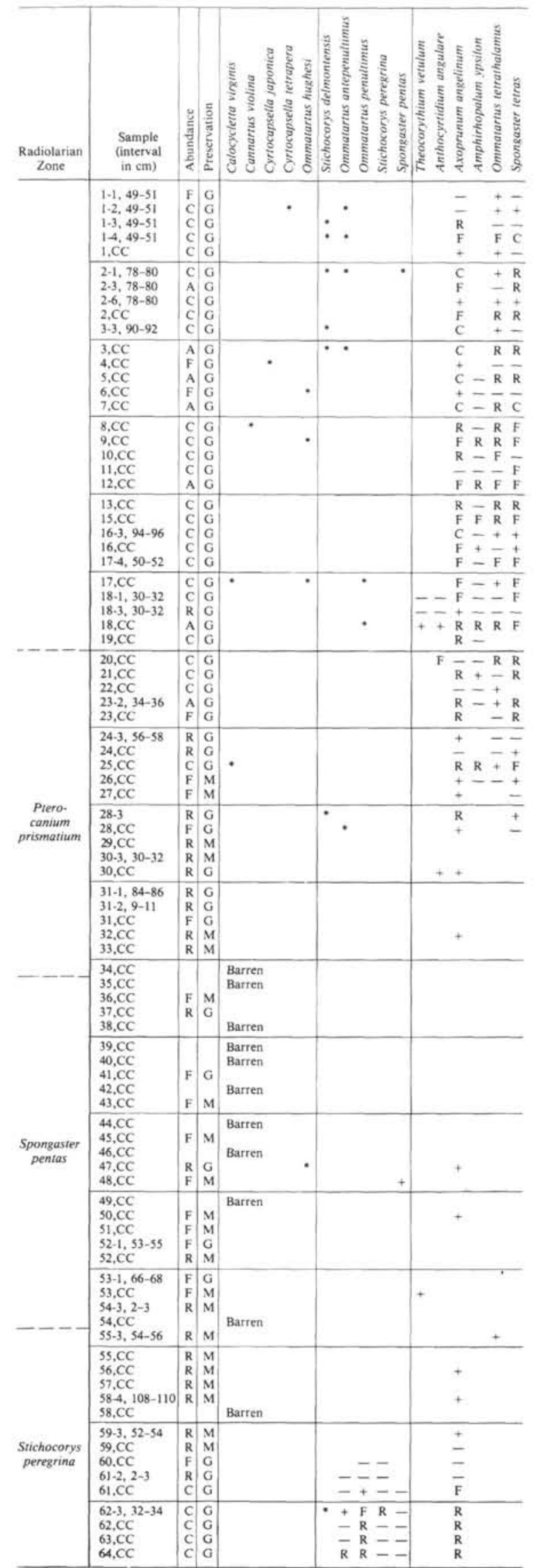

Table 7. Radiolarians at Site 491.

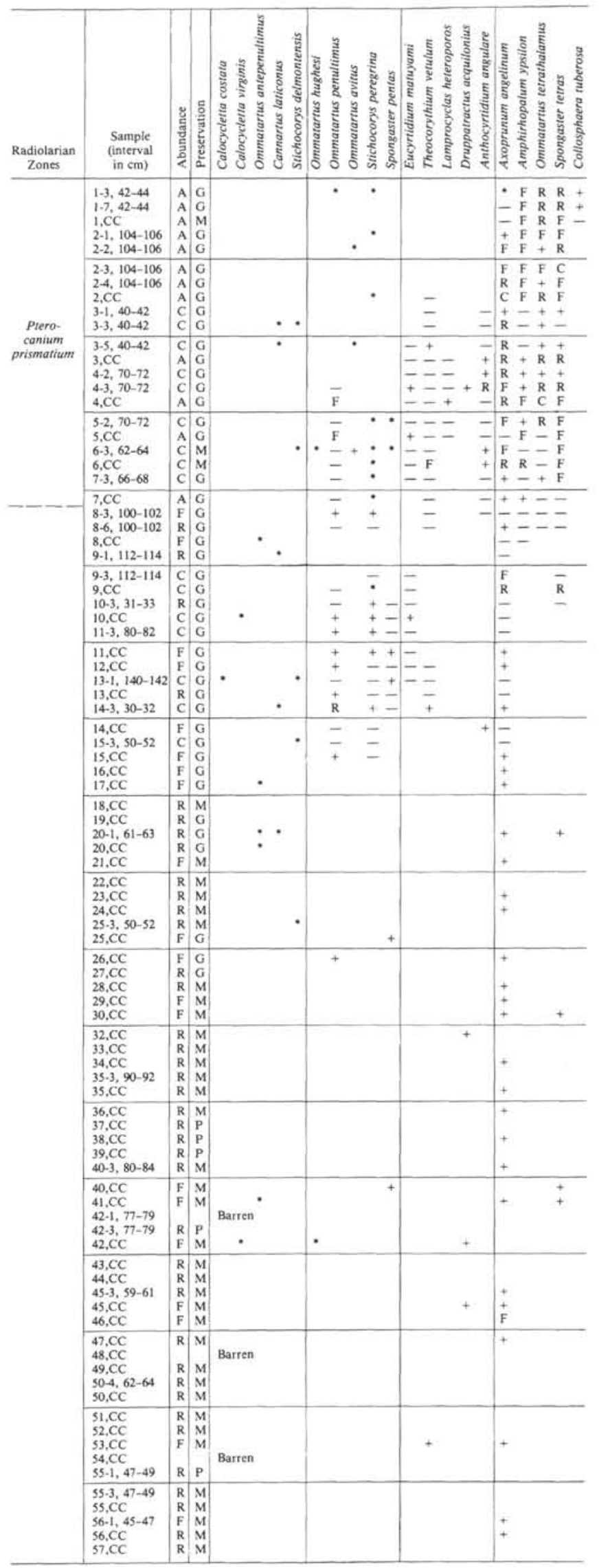


Table 8. Radiolarians at Site 492.

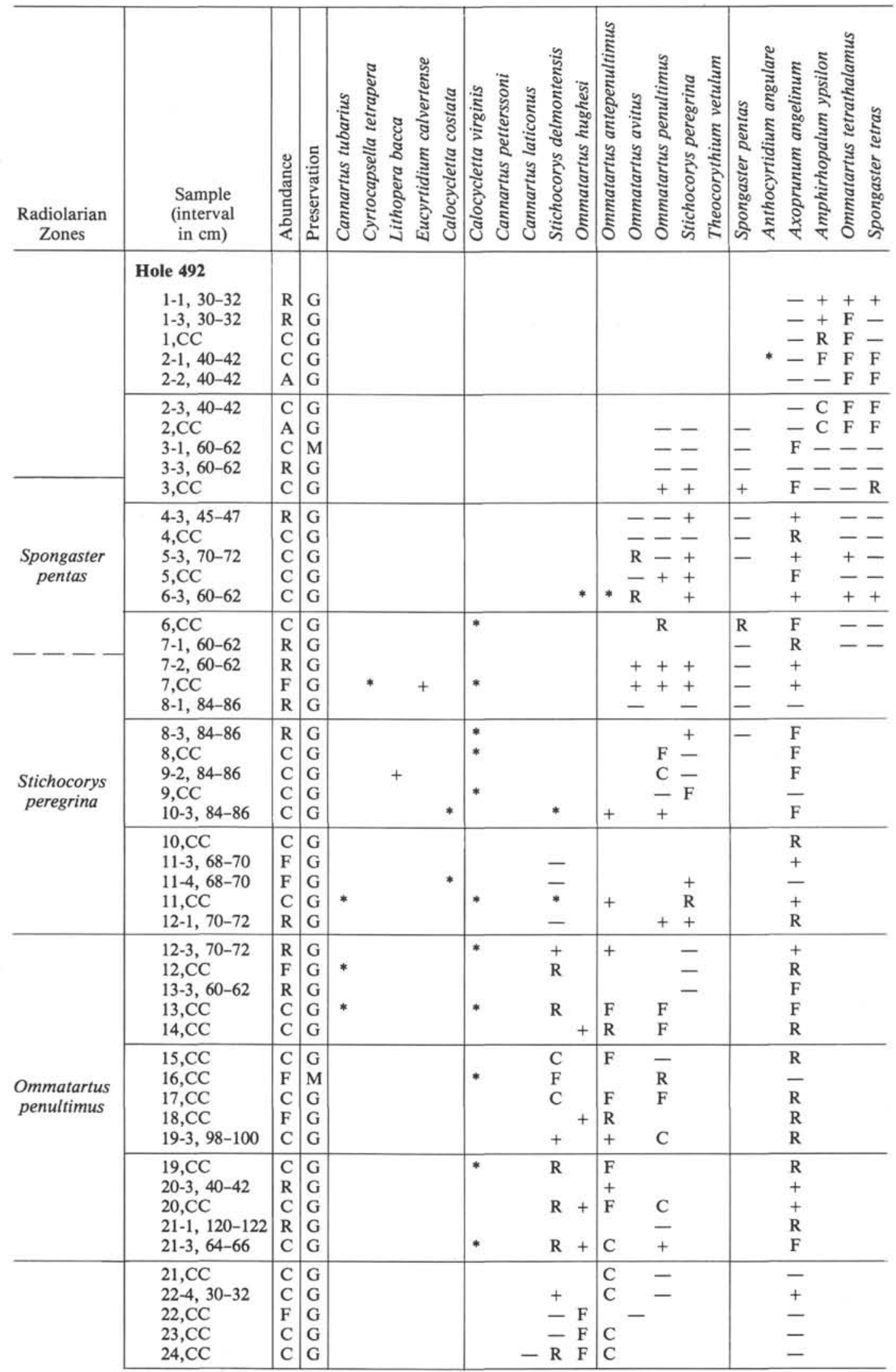


Table 8. (Continued).

\begin{tabular}{|c|c|c|c|c|c|c|c|c|c|c|c|}
\hline $\begin{array}{c}\text { Radiolarian } \\
\text { Zones }\end{array}$ & $\begin{array}{c}\text { Sample } \\
\text { (interval } \\
\text { in } \mathrm{cm} \text { ) }\end{array}$ & 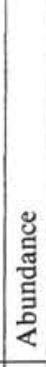 & 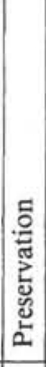 & 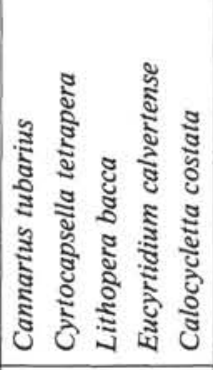 & 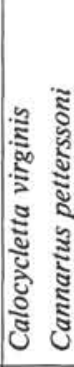 & 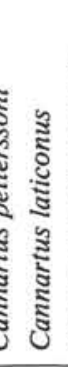 & 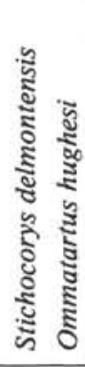 & 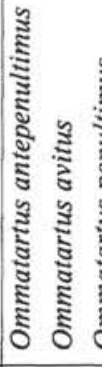 & 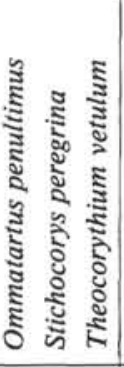 & 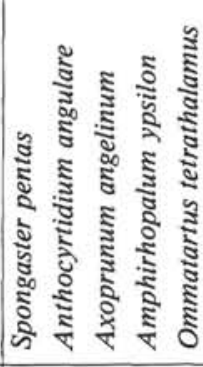 & 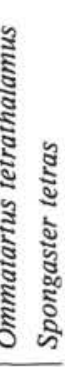 \\
\hline \multirow[t]{6}{*}{$\begin{array}{l}\text { Ommatartus } \\
\text { ante- } \\
\text { penultimus }\end{array}$} & $\begin{array}{l}25, \mathrm{CC} \\
26, \mathrm{CC} \\
27, \mathrm{CC} \\
28, \mathrm{CC} \\
29, \mathrm{CC}\end{array}$ & $\begin{array}{l}\mathrm{C} \\
\mathrm{C} \\
\mathrm{C} \\
-\mathrm{C}\end{array}$ & $\begin{array}{l}G \\
G \\
G \\
G \\
G\end{array}$ & & + & $\begin{array}{r}- \\
-\bar{F} \\
+R\end{array}$ & $\begin{array}{r}\mathrm{F} \\
\mathrm{R} \text { C } \\
-\mathrm{R} \\
-\mathrm{R}- \\
\end{array}$ & $\frac{-}{\bar{F}}$ & & & \\
\hline & $\begin{array}{l}30, \mathrm{CC} \\
31, \mathrm{CC}\end{array}$ & $\begin{array}{l}\mathrm{C} \\
\mathrm{A}\end{array}$ & $\begin{array}{l}\mathrm{G} \\
\mathrm{G} \\
\end{array}$ & & & $\begin{array}{l}\mathrm{R} \\
\mathrm{F} \\
\end{array}$ & $\begin{array}{ll}\mathrm{R} & - \\
\mathrm{R} & \mathrm{C}\end{array}$ & $\begin{array}{l}\mathrm{F} \\
\mathrm{R} \\
\end{array}$ & & & \\
\hline & $\begin{array}{c}\text { Hole 492A } \\
\text { 1, ᄂ } \\
2, \mathrm{CC} \\
3, \mathrm{CC} \\
4, \mathrm{CC} \\
5-2,88-90\end{array}$ & $\begin{array}{l}A \\
C \\
C \\
R \\
C\end{array}$ & $\begin{array}{l}G \\
G \\
G \\
G \\
G\end{array}$ & & & & & & -+ & 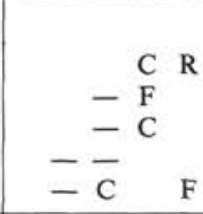 & F F \\
\hline & $\begin{array}{l}6-1,124-126 \\
6-2,124-126 \\
6, C C \\
7-1,78-80 \\
7-2,58-60\end{array}$ & $\begin{array}{l}C \\
C \\
C \\
C \\
C\end{array}$ & \begin{tabular}{|l|}
$G$ \\
$G$ \\
$G$ \\
$G$ \\
$G$
\end{tabular} & & & & & $\frac{-}{\bar{R}}$ & $\begin{array}{ccc} & - & \mathrm{R} \\
& * & + \\
- & * & + \\
* & * & \\
\mathrm{~F} & \mathrm{~F} & \end{array}$ & $\begin{array}{ll}- & \text { F } \\
+ & F \\
+ & F \\
R & \end{array}$ & $\begin{array}{r}\mathrm{R} \\
+\mathrm{R} \\
+ \\
\mathrm{R} \\
+\end{array}$ \\
\hline & $\begin{array}{l}7, \mathrm{CC} \\
8-1,105-107 \\
8, \mathrm{CC} \\
9-1,90-92 \\
9, \mathrm{CC}\end{array}$ & $\begin{array}{l}C \\
C \\
C \\
C \\
C\end{array}$ & \begin{tabular}{|l|}
$G$ \\
$G$ \\
$G$ \\
$G$ \\
$G$
\end{tabular} & & & & * & $\begin{array}{l}\mathrm{R} \\
- \\
\mathrm{F} \\
-\end{array}$ & $\begin{array}{ll}\mathrm{F} & \mathrm{R} \\
& \mathrm{F} \\
\mathrm{F} & \mathrm{R} \\
\mathrm{F} & \mathrm{R} \\
\mathrm{F} & -\end{array}$ & $\begin{array}{l}-\mathrm{R} \\
- \\
-\end{array}$ & \\
\hline & $\begin{array}{l}10, \mathrm{CC} \\
11, \mathrm{CC}\end{array}$ & $\begin{array}{l}\mathrm{A} \\
\mathrm{C}\end{array}$ & $\begin{array}{l}\mathrm{G} \\
\mathrm{G}\end{array}$ & & $*$ & * & $\stackrel{*}{+}$ & $\begin{array}{l}\mathrm{C} \\
\mathrm{F}\end{array}$ & $\begin{array}{ll}C & F \\
C & -\end{array}$ & + & + \\
\hline
\end{tabular}

within Sites 490 and 493 might be due to silica dissolution, because sedimentation rates in these intervals are not high enough for the absence of radiolarians to be caused by sediment dilution only. Radiolarian recrystallization occurs in the lower Miocene sediments of Sites 489 and 493.

Reworking of older forms is a biostratigraphic problem at trench slope Sites $488,490,491$, and 492 and is especially serious because reworking often occurred so soon after deposition that radiolarians from one zone were reworked into the next succeeding zone. This type of reworking, a result of the youthful age and tectonic instability of this margin, sometimes makes it virtually impossible to recognize the extinction level of index species.

Loss of a portion of the radiolarian fauna is another problem for biostratigraphic determinations. The abundance of nassellarian radiolarians fluctuates greatly throughout the Neogene section recovered in Leg 66 sediments. This variation is expressed as the the ratio of nassellarian to spumellarian radiolarians in Leg 66 cores in Figure 1. Upper Quaternary sediments contain abundant nassellarians, but their number decreases downhole until they are nearly absent in some Pliocene samples. Nassellarian abundances fluctuate throughout the late Miocene but are generally low. Lower Miocene sediments have a high ratio with about equal numbers of nassellarians and spumellarians. This low of nassellarians in Pliocene and lower Pleistocene sediments has some serious consequences for biostratigraphy. The nassellarian radiolarian Pterocanium prismatium is totally absent from the Leg 66 area, and other nassellarians such as Anthocyrtidium angulare and Stichocorys peregrina are not very abundant.

Definite explanations for the loss of nassellarian radiolarians have not been found; however, there are a few possible causes. Nassellarian abundance decreases inshore in modern radiolarian assemblages collected from offshore Texas (Casey and Bauer, 1976). Apparently, nassellarians prefer more "open ocean" conditions, whereas spumellarians can survive nearshore. A decrease in the ratio of nassellarians to spumellarians to a minimum value offshore Guatemala was correlated with the late Pleistocene lowering in sea level which moved nearshore environments with fewer nassellarians offshore (McMillen, 1979). This same effect could have contributed to the loss of nassellarians in Pliocene and lower Pleistocene sediments offshore southern Mexico, as this has been established to be a period of generally lowered sea level (Vail and Mitchum, 1979). However, 
Table 9. Radiolarians at Site 493.

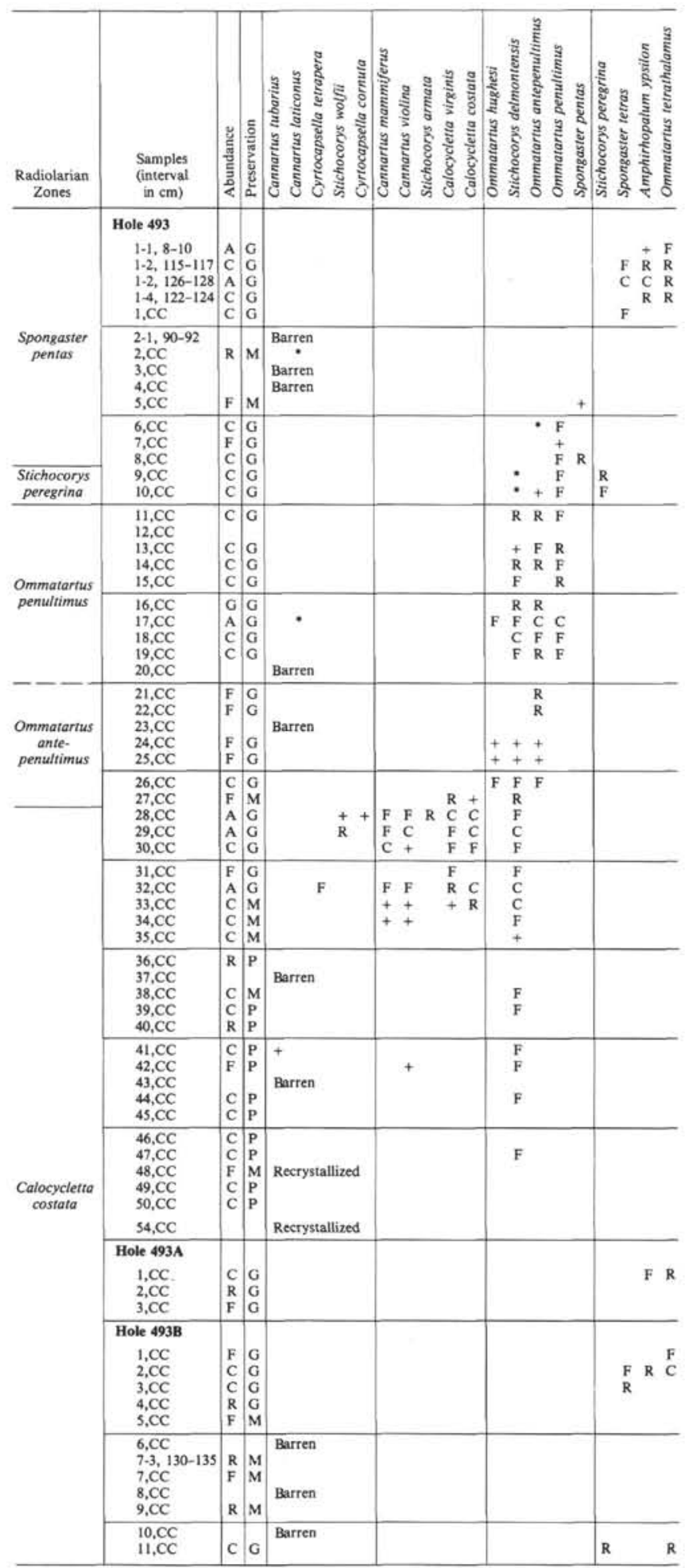

this ratio could also be the result of general oceanographic changes in the East Pacific. The loss of nassellarian radiolarians does seem to be a special aspect of nearshore environments and might be a recurrent problem in continental margin studies.

The eastern boundary currents of the Eastern Pacific seem to have some influence on the Quaternary radio- larian assemblages at this latitude. The Quaternary equatorial zonation of Nigrini (1971), which has been successfully used in the central equatorial Pacific (Johnson, 1976) and eastern equatorial Pacific (Dinkelman, 1973), could not be used offshore southern Mexico owing to the absence of the collosphaerid Buccinosphaera invaginata and virtual absence of Collosphaera tuber$o s a$, which are used to define the upper two zones, although other species of Nigrini's zones such as Amphirhopalum ypsilon, Anthocyrtidium angulare, and Theocorythium vetulum are present. Both collosphaerid species are also absent south of the equator near the South America coast (Sachs, 1976). Apparently, Nigrini's late Quaternary zones are restricted in latitudinal distribution, especially in the East Pacific. Both of these collosphaerids have been shown to inhabit surface waters (Casey et al., 1979; McMillen and Casey, 1978) and upwelling associated with eastern Pacific boundary currents might exclude these species.

Several of the species used by Hays (1970) in his North Pacific Quaternary zonation occur in varying abundances; Axoprunum angelinum ( $=$ Stylatractus universus) is commonly present in Miocene through upper Pleistocene sediments, and its extinction level of 0.40 m.y. can be recognized in all Leg 66 sites except in coarse clastics at Site 486 and at Site 493 . Other species used in Hays's scheme-Eucyrtidium matuyami, E. calvertense, Druppatractus acquilonius, and Lamprocyclas heteroporos - are either absent or very rare so that the zonation cannot be applied. The radiolarian fauna offshore southern Mexico seems in part to be intermediate between those in the equatorial and North Pacific.

The combined effects of collosphaerid removal by oceanographic effects and the loss of nassellarians in lower Pleistocene and in Pliocene sediments make zonation difficult enough without the additional problems of extensive reworking and dilution by clastic sediments. Trench sediments are especially difficult to zone because of problems of dilution and dissolution. Ages of inferred trench sequences in Sites 488, 491, and 492 were determined from dates of the overlying lower slope deposits. Dating trench deposits in ancient accretionary zones would have to proceed on similar lines to arrive at accurate ages. This means slope deposits overlying the accretionary zone will have to be identified in these older sequences, which could be a problem in sequences composed mostly of deformed trench deposits with a small volume of slope deposits in stratigraphic contact with the wedge.

\section{LIST OF SPECIES}

Amphirhopalum ypsilon Haeckel, 1887, p. 522 Nigrini, 1967, p. 35, pl. 3, fig. 32d.

Anthocyrtidium angulare Nigrini, 1971, p. 445, pl. 34.1 , fig. 32b.

Axoprunum angelinum (Campbell and Clark), Kling, 1973, p. 634, pl. 1, figs. 13-16; pl. 6, figs. 14-18.

Calocycletta costata (Riedel), Riedel and Sanfilippo, 1970, p. 535, pl. 14 , fig. 12.

Calocycletta virginis (Haeckel), Riedel and Sanfilippo, 1970, p. 535, pl. 14, fig. 10.

Cannartus laticonus Riedel, 1959, p. 291, pl. 1, fig. 5.

Cannartus mammiferus (Haeckel), Riedel, 1959, p. 291, pl. 1, fig. 4. 


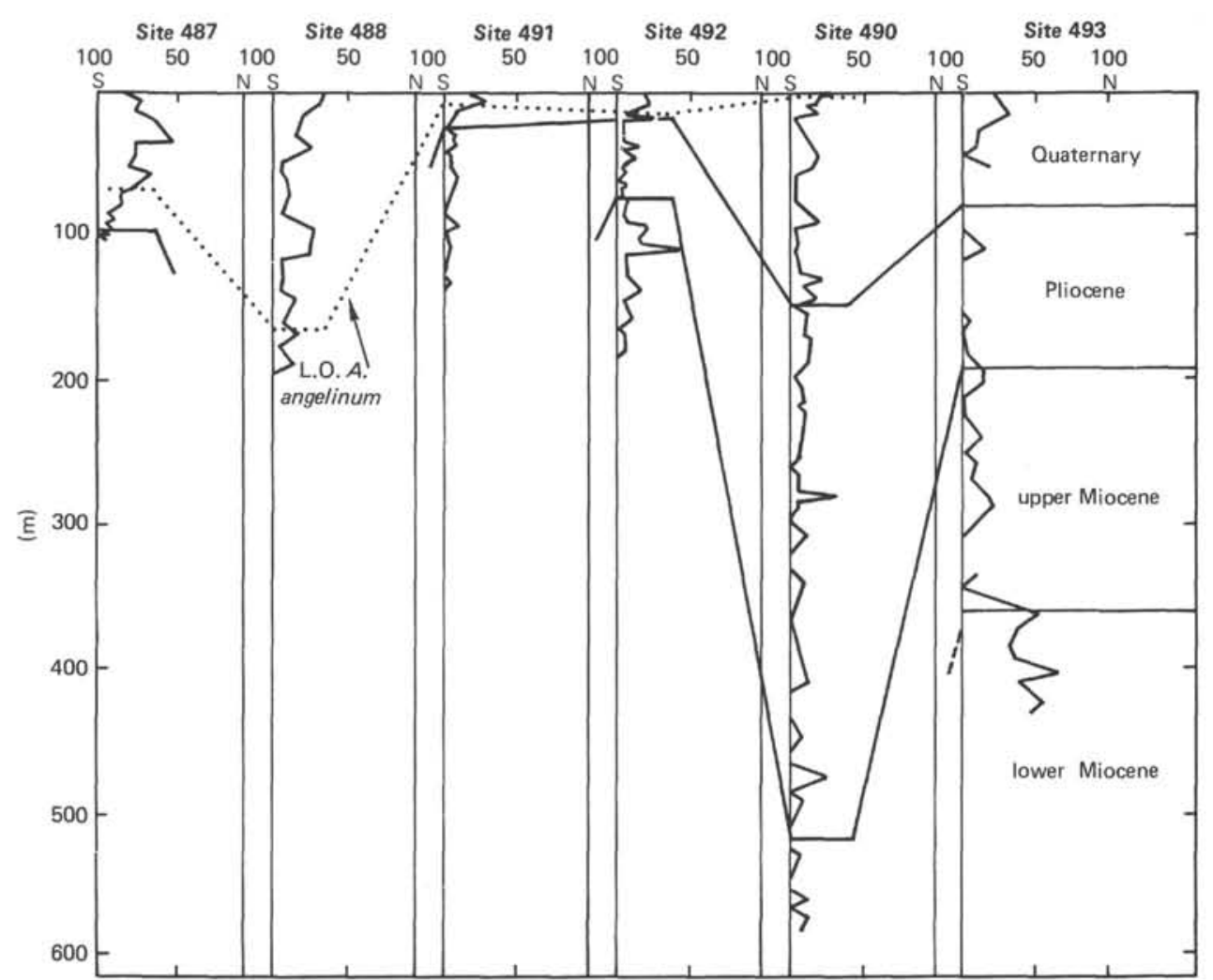

Figure 1. The ratio of nassellarian to spumellarian radiolarians at some Leg 66 sites. The loss of nassellarians in early Quaternary, Pliocene, and upper Miocene sediments might be related to lowered sea level at this time or to different oceanographic conditions. Early Miocene ratios are more nearly like those at present. Most faunas are generally well preserved, so dissolution probably has not been a significant factor in the loss of nassellarians. Age designations in Site 493 column apply to other sites as indicated by solid lines.

Cannartus petterssoni Riedel and Sanfilippo, 1970, p. 520, pl. 14, fig. 3.

Cannartus prismaticus (Haeckel), Riedel and Sanfilippo, 1970, p. 520, pl. 15 , fig. 1.

Cannartus tubarius (Haeckel), Riedel and Sanfilippo, 1970, p. 520, pl. 15 , fig. 2.

Cannartus violina Haeckel, 1887, p. 358, Riedel, 1959, p. 290, pl. 1, fig. 3.

Collosphaera tuberosa Haeckel, 1887, p. 97; Nigrini 1971, p. 445, pI. 34.1 , fig. 1 .

Cyrtocapsella cornuta (Haeckel), Sanfilippo and Riedel, 1970, p. 453, pl. 1, figs. 19, 20.

Cyrtocapsella japonica (Nakaseko), Sanfilippo and Riedel, 1970, p. 452 , pl. 1, figs. 13-15.

Cyrtocapsella tetrapera (Haeckel), Sanfilippo and Riedel, 1970, p. 453 , pl. 1 , figs. $16-18$.

Druppatractus acquilonius Hays, 1970, p. 214, pl. 1, figs. 4, 5 .

Eucyrtidium calvertense Martin, 1904, p. 450 , pl. 130, fig. 5 .

Eucyrtidium matuyami Hays, 1970, p. 213, pl. 1, figs. 7-9.

Lamprocyclas heteroporos Hays, 1965 , pp. 179-180, fig. 1 .

Lithopera bacca Ehrenberg, 1872, p. 314; Nigrini, 1967, p. 54, pl. 6, fig. 2.

Lychnocanium bipes Riedel, 1959, p. 294, figs. 5, 6; Dinkelman, 1973, p. 780 , pl. 6 , fig. 1 .

Ommatartus antepenultimus Riedel and Sanfilippo, 1970, p. 521, pl. 14.

Ommatartus avitus (Riedel), Riedel and Sanfilippo, 1971, p. 1588, pl. 4 , fig. 6.

Ommatartus hughesi (Campbell and Clark), Riedel and Sanfilippo, 1970 , p. 521.

Ommatartus penultimus (Riedel), Riedel and Sanfilippo, 1970, p. 521, 1971, pl. 1C, figs. 5-7.

Ommatartus tetrathalamus (Haeckel), Riedel and Sanfilippo, 1971, p. 1588, pl. 1C, figs. 5-7.
Spongaster pentas Riedel and Sanfilippo, 1970, p. 523, pl. 15, fig. 3. Spongaster tetras Ehrenberg, 1860, p. 833; Nigrini, 1967, p. 41, pl. 5, figs. 1a, 1b, 2.

Stichocorys armata (Haeckel), Riedel and Sanfilippo, 1971, p. 1595 , pl. 2E, figs. 13-15.

Stichocorys delmontensis (Campbell and Clark), Sanfilippo and Riedel, 1970 , p. 451 , pl. 1, fig. 9.

Stichocorys peregrina (Riedel), Riedel and Sanfilippo, 1970, p. 530; 1971 , pl. 8 , fig. 5 .

Stichocorys wolfii Haeckel, 1887, p. 1479; Riedel, 1954, p. 173, pl. 1, fig. 4; Riedel and Sanfilippo, 1971, pl. 2E, figs. 8, 9.

Theocorythium vetulum Nigrini, 1971, p. 447, pl. 34.1, figs. $6 \mathrm{a}, 6 \mathrm{~b}$.

\section{ACKNOWLEDGMENTS}

I am grateful to Richard Casey and Jean Westberg for reviewing the manuscript.

\section{REFERENCES}

Berggren, W. A., and Van Couvering, J. A., 1974. The Late Neogene: Amsterdam (Elsevier).

Campbell, A. S., and Clark, B. L., 1944. Miocene radiolarian faunas from Southern California. Geol. Soc. Am. Spec. Pap. 51 .

Casey, R. E., and Bauer, M. A., 1976. A seasonal study of radiolaria and foraminifera in the waters overlying the south Texas outer continental shelf. Geol. Soc. Am. Abstr. with Programs, 8 (No. 1):11. (Abstract)

Casey, R., Spaw, T. M., Kunze, F., et al., 1979. Radiolarian ecology and the development of the radiolarian component in Holocene sediments, Gulf of Mexico and adjacent seas with potential paleontological implications. Trans. Gulf Coast Assoc. Geol. Soc., 29:228-237.

Dinkelman, M. G., 1973. Radiolarian Stratigraphy: Leg 16, Deep Sea Drilling Project. In van Andel, Tj. H., Heath, G. R., et al., Init. 
Repts. DSDP, 16: Washington (U.S. Govt. Printing Office), $747-$ 813.

Ehrenberg, C. G., 1860. Uber den Tiefgrund des stillen Oceans zwischen Californien und den Sandwich-Inseln aus bis 15,600 Tiefe nach Lieut. Brooke, Mper. Preuss. Akad. Wiss. Berlin, Jahre 1860, pp. 819-833.

1872. Mikrogeologischen Studien als Zusammenfassung der Beobaditungen des Kleinsten Lekens der Meeres Tiefgrunde aller zonen und dessen geologischen Einfluss. Kgl. Preuss. Akad. Wiss. Berlin, Monatsber. Jahre 1872, pp. 263-322.

Haeckel, E., 1887. Report on the radiolaria collected by H.M.S. Challenger during the years 1873-76. Rept. Voyage Challenger, Zool., v. 18, Pts. I, II: Edinburgh.

Hays, J. D., 1965. Radiolaria and late Tertiary and Quaternary history of Antarctic seas. Biology of Antartic Seas II, Antarctic Research Ser. 5: Washington (Am. Geophys. Union), pp. 124-184.

1970. Stratigraphy and evolutionary trends of radiolaria in North Pacific deep-sea sediments. Geol. Soc. Am. Mem. 126 185-218.

Johnson, D. A., 1976. Cenozoic radiolarians from the Central Pacific, DSDP Leg 33. In Schlanger, S. O., Jackson, E. D., et al., Init. Repts. DSDP, 33: Washington (U.S. Govt. Printing Office), 425-437.

Kling, S. A., 1973. Radiolaria from the Eastern North Pacific, Deep Sea Drilling Project, Leg 18. In Kulm, L. D., von Huene, R., et al., Init. Repts. DSDP, 18: Washington (U.S. Govt. Printing Office), 617-671.

McMillen, K. J., 1979. Radiolarian ratios and the Pleistocene-Holocene boundary. Trans. Gulf Coast Assoc. Geol. Soc., 29:298-301.

McMillen, K. J., and Casey, R. E., 1978. Distribution of living polycystine radiolarians in the Gulf of Mexico and Caribbean Sea, and comparison with the sedimentary record. Mar. Micropaleont., $3: 121-145$.
Martin, G. C., 1904. Radiolaria. Maryland Geological Survey (Miocene), pp. 447-459.

Nigrini, C., 1967. Radiolaria in pelagic sediments from the Indian and Atlantic oceans. Bull. Scripps Inst. Oceanog., 11.

1971. Radiolarian zones in the Quaternary of the Equatorial Pacific Ocean. In Funnell, B. U., and Riedel, W. R. (Eds.), The Micropaleontology of Oceans: Cambridge (Cambridge University Press), pp. 443-461.

Riedel, W. R., 1954. The age of the sediment collected at Challenger Station 225, and the distribution of Ethmodiscus rex. Deep-Sea Res., 1:170-175.

1959. Oligocene and lower Miocene radiolaria in tropical Pacific sediments. Micropaleontology, 5:295-302.

Riedel, W. R., and Sanfilippo, A., 1970. Radiolaria, Leg 4, Deep Sea Drilling Project. In Bader, R. G., Gerard, R. D., et al., Init. Repts. DSDP, 4: Washington (U.S. Govt. Printing Office), 503575.

1971. Cenozoic radiolaria from the Western Tropical Pacific, Leg 7. In Winterer, E. L., Riedel, W. R., et al., Init. Repts. DSDP, 7, Pt. 2: Washington (U.S. Govt. Printing Office), 1529-1672.

1978, Stratigraphy and evolution of tropical Cenozoic radiolarians. Micropaleontology, 24(no. 1):61-96.

Sachs, H. M., 1976. Nazca Plate radiolarian distributions: Evidence from DSDP Sites 319, 320, and 321. In Yeats, R. S., Hart, S. R., et al., Init. Repts. DSDP, 34: Washington (U.S. Govt. Printing Office), 713-714.

Vail, P. R., and Mitchum, R. M., Jr., 1979. Global cycles of relative changes of sea level from seismic stratigraphy. In Watkins, J. S. Montadert, L., and Dickerson, P. W. (Eds.), Geological and Geophysical Investigations of Continental Margins: Mem. Am. Assoc. Pet. Geol. 29:469-472. 